\title{
Teaching and Testing Sociopragmatics in the Russian Language Classroom
}

\author{
By Wolfgang Stadler
}

The purpose of this paper is to highlight the importance of sociolinguistic and pragmatic features in the teaching and testing processes of Russian as a foreign language with Austrian university students. Teachers of Russian seem to have a preference for linguistic competences, such as phonetics, morphology, syntax and lexis, hereby neglecting or even ignoring sociopragmatic features - especially when testing students' achievement or proficiency on various competence levels. This paper presents suggestions for how to move from awareness-raising exercises to communicative tasks in order to strengthen the students' sociopragmatic skills; furthermore it discusses the role of various forms of authenticity in the Russian language classroom, such as competence authenticity and voice authenticity, among others. Teachers wanting to improve students' communicative competence need to be made aware of the fact that incorporating sociopragmatic features into their teaching and testing is not so much dependent on the choice of material, but rather on what they are going to do with it. It is acceptable to use adapted or stylized material besides authentic texts in class in order to generate authentic performances in which students can demonstrate an understanding of sociopragmatic skills.

Keywords: Pragmatics, Sociolinguistics, Teaching and Testing Sociopragmatics, Communicative Competence, Authenticity.

\section{Introduction}

Pragmatics is defined as the study of how we use language in interaction (e.g. Röver, 2005, p.3). The Common European Framework of Reference for Languages (CEFR, 2001, p.13) considers pragmatic - together with linguistic (grammatical, lexical) and sociolinguistic - knowledge to be the core components of communicative competence. In order to develop and accomplish purposeful actions (or tasks) successfully, both teachers and learners need pragmatic knowledge, which, according to Bachman \& Palmer (2010, pp.46-47), consists of functional and sociolinguistic knowledge. So, in other words, students need both illocutionary and sociolinguistic competence in order to create, interpret and adequately react to utterances. Teachers have to ask themselves what "kinds of semantic relation" (CEFR, 2001, p.116) learners should be equipped with to build up appropriate discourse and how "qualitative progress" in the sociopragmatic component can be achieved (CEFR, 2001, p.130). For the sake of convenience, I use the term "sociopragmatics" in this paper, encompassing both pragmalinguistic and sociopragmatic components as understood and defined by Leech 1983 (see also Kasper, 1997; Roever, 2011).

\footnotetext{
* Professor, University of Innsbruck, Austria.
} 
Kolotova \& Kofanova (2012, p.1) understand linguistic competence as a matter of phonetics, grammar, semantics and pragmatics. They define the latter as "knowing the rules of verbal behaviour in various situations." In their opinion, pragmatic knowledge consists of the speaker's intention(s), the recipient's reaction(s) and their appropriate choice of expressions. Apart from getting utterances grammatically and organisationally correct, learners should relate their utterances to a communicative goal and to the corresponding features of the communication situation.

For learners and students of Russian in Austria, this language is normally their third, fourth or even fifth one. This paper tries to answer the following questions:

- Can we assume that learners of Russian transfer pragmatic knowledge from their L1, or will it have to be facilitated by explicit teaching and awareness raising?

- If pragmalinguistic and sociopragmatic techniques and strategies are taught, how can they be tested by setting tasks that require a certain range of functional and sociolinguistic items on a certain level, e.g. on the independent level?

- What role does authenticity play in the teaching and testing of sociopragmatic features?

\section{Overview}

Testing pragmatic and sociolinguistc features in the foreign language classroom would presuppose that we (can actually) teach sociopragmatics in the first place. Brock \& Nagasaka (2005, p.24) agree that the English Foreign Language (EFL) classroom can be an ideal setting for learners "to begin developing pragmatic competence in English." Kasper (1997, p.1), on the other hand, argues that "[c]ompetence, whether linguistic or pragmatic, is not teachable," later modifying her statement by saying that "pragmatic ability can indeed be systematically developed through planful classroom activities" (Kasper, 1997, p.10). With their statements, both Brock \& Nagasaka (2005) and Kasper (1997) imply that in order to (systematically) develop pragmatic competence it needs to be taught. It is true that we cannot test competences be they linguistic, pragmatic or sociolinguistic - directly, but what we can do is to draw inferences about language proficiency from the sociopragmatic construct put to use. To my mind, this can only be achieved if authenticity plays a major role both in teaching and testing. In my paper I will try to show which role authenticity can play or should play when teaching and testing Russian sociopragmatic faetures.

Most of the research on teaching and testing pragmatics focuses on second language acquisition (of English) (cf. Roever's Section on Interlanguage Pragmatics, 2011, pp.465-467). In Austria, however, pupils at school or students at university learn Russian mostly as their third, fourth, or even as 
their fifth language. This means pupils and students are communicatively competent in at least two (or more) other languages and supposedly know how to transfer this ability to Russian in use. Generally, as they develop receptive skills more quickly and easily, they can be challenged with and exposed to the understanding of authentic texts at an earlier stage than to producing speaking and writing performances comparable to native speakers' authentic texts, which they do with more difficulty.

This paper shows, how, with the use of both adapted and authentic texts, written for the classroom setting or coming from the real world, sociopragmatic awareness can be raised among students of Russian as a foreign language, and how the use of sociopragmatic features can be tested in the Russian language classroom.

\section{Teaching Sociopragmatics}

Teaching sociopragmatics calls for a construct that can be put to use at various competence levels. Bardovi-Harlig \& Mahan-Taylor (2003) define six areas of teaching sociopragmatics in the foreign language classroom: speech acts, conversational structure, conversational implicature, conversational management, discourse organization, and sociolinguistic aspects of language use, such as choice of address forms. With regard to teaching methods, the authors recommend authentic language samples to be used as examples or models, and that input precedes interpretation or production by learners. This means that the areas mentioned above need to be taught in awareness-raising situations before they can be taught in interaction. Pupils and students should be motivated to discover how language works, and they should be eager to explore which rules and conventions guide their use of language in context (cf. Bardovi-Harlig, 2013, p.78). Even CEFR (2001, p.13) suggests the "drawing on scenarios or scripts of interactional exchanges" when teaching pragmatic competence. If the aim of communicative language teaching is, among others, "sociolinguistic finesse and pragmatic effectiveness" (CEFR, 2001, p.136), these sociopragmatic features should definitely be included in the construct of teaching and testing. As already mentioned, we may, of course, assume that sociopragmatic knowledge from L1 is employed when putting rules into practice in the Russian language classroom. Nevertheless, it helps to teach, to practise and set explicit tasks in order to develop and activate sociopragmatic knowledge and competence.

I will now present two models, one from Kursk University (Russia) and the other from Innsbruck University (Austria) to show how sociopragmatic features can be part of teaching situations in the Russian language classroom or lecture room.

\section{The Kursk Model - An Example of Sociopragmatic Awareness-raising}

Kolotova \& Kofanova (2012, p.4) have developed an exercise, which they use in class with students of Russian as a foreign language. Learners are given 
two dialogues in two situations that have obviously been written by the authors themselves for pedagogic reasons. Maxim has come to another town to visit his friend Andrei. On a very hot day he returns home after shopping, finding that he has left the flat without Andrei's keys. Andrei is not home yet. So Maxim has to ask

a) a mutual friend, Ivan, whom he knows very well and who is just returning home to the neighbouring flat (dialogue 1)

b) a very busy neighbour, Anatoliy Vasilyevich, who he has never spoken to and whom he does not know at all (dialogue 2)

whether he can ...

... use his cell-phone to ring Andrei

... wait in the friend's / busy neighbour's flat until Andrei returns

... have a glass of water

The exercise focuses on the different realizations of utterances, the relationships between the interlocutors, the size of the favor or request, and the expression of politeness in dialogues 1 and 2 .

In the exercise, students need to identify speech acts functioning as requests, copy them into a table and highlight the differences between them, estimate the size of the request on a scale from 1 (very small) to 5 (very big), describe the relationships between the interlocutors on a scale from 1 (unacquainted) to 5 (very close), and define the expression of politeness on a scale from 1 (inadequate) to 5 (very adequate).

According to the authors, the objective of the exercise is to comprehend speech intentions. This is achieved by activating lexis and raising students' language awareness so that they can select appropriate language material, when having to express themselves in similar situations. Kolotova \& Kofanova (2012) agree that the aim of including pragmatics into the teaching of Russian as a foreign language lies in the fact that students should be equipped with the knowledge of how to use language in order to achieve a corresponding impact on the interlocutor.

The exercise used by Kolotova \& Kofanova (2012) consists of identifying pragmalinguistic functions and understanding sociopragmatic features, as no productive or creative activity like impersonating the dialogue or staging a similar role-play has to be carried out. The exercise can be seen as a pre-task and a prerequisite among many others for activating productive skills, but it can by no means be regarded as a replacement for them, as its main focus lies on form and meaning, and not on language in use.

The Innsbruck Model - An Example of using Particles in Dialogues

In a seminar on Literacy and Orality in the Russian Language Classroom taught for pre-service teacher trainees of Russian at Innsbruck University, students were confronted with three types of dialogues among interlocutors having a close relationship to each other - one taken from a Russian course book (Level B1), the other from a collection of transcribed Russian 
conversations by native speakers, the third from a screenplay and its corresponding film scene. The students' task was to compare and contrast the three texts, the first written for pedagogic use, the second to demonstrate oral stylization in written texts, and the third being an example of "staged communication" by actors in a film. Having completed the task, the students discovered that the course book dialogue lacked authenticity in comparison with the other texts, which, in their opinion, was due to the unnatural staccato tone and the missing intimacy among the interlocutors' speech. The apodictic and harsh tone of voice in the course book dialogue could be counteracted and improved by "using, with reasonable accuracy, a wide range of modification devices" (CEFR, 2001, p.36), since the students found these modification devices were most characteristic of the other texts. The active use of particles, interjections and modification devices is a skill which is not developed before C2 level, but students at a lower level, e.g. at B1, are able to grasp and understand these function words intuitively.

After this critical awareness task, students moved on to rewriting course book dialogues to make them sociolinguistically more adequate, pragmatically more efficient and prosodically lighter in tone. In other words: the new dialogues seemed to be more authentic from the perspective of text authenticity but also from the perspective of voice authenticity (see Section 4 below), features that could be strengthened if course book authors were willing to adapt language for classroom use in a more natural, i.e. sociopragmatically more appropriate and more efficient way.

\section{Introducing Authenticity}

The Common European Framework of Reference for Languages (CEFR, 2001) equates authenticity of language with the concept of text authenticity, i.e. the use of authentic materials in contrast to adapted or pedagogic texts. Apart from text authenticity, CEFR also mentions authentic (work and study-related) situations, authentic (communicative) interaction, authentic discourse and authentic spoken utterances. Yet CEFR's main focus is definitely on text authenticity or "direct exposure to authentic use of language in L2," which includes spoken utterances and written (printed, typewritten, handwritten) texts (CEFR, 2001, p.143). Authentic texts are seen in opposition to texts "specially designed for teaching purposes, texts in textbooks or texts produced by learners" (CEFR, 2001, p.16).

Another conceptualization of authenticity is presented by MacDonald, Badger \& Dasli (2006). According to them, apart from text authenticity, there are three other concepts of authenticity that are frequently discussed in the literature of applied linguistics: competence authenticity, learner authenticity and classroom authenticity (MacDonald, Badger \& Dasli, 2006, pp.251-253). These concepts are used with two different meanings - the meaning of correspondence (text authenticity, competence authenticity and learner authenticity) and the meaning of genesis (classroom authenticity). Text 
authenticity represented by collocations such as authentic text, authentic language and authentic material is not seen as the opposite of "real world" language, texts and artifacts (MacDonald, Badger \& Dasli, 2006, p.252) but as corresponding to classroom texts and "real world" texts used outside the language classroom. Competence authenticity, to their mind, corresponds with Canale \& Swaine's language competence model from the 1980s, which comprises grammatical, sociolinguistic and strategic competence as enabling factors of communicative interaction among native (and non-native) speakers. Learner authenticity corresponds with the realization of intention and the appropriate way of responding to it. Classroom authenticity, the fourth concept, derives from an authenticity of genesis, meaning that pedagogic texts must be considered authentic as they emerge from the classroom as "their point of origin" (MacDonald, Badger \& Dasli, 2006, p.253).

Roberts \& Cooke's categorization distinguishes between two types of authenticity in language teaching contexts: the authenticity of (pedagogic) materials, on the one hand, and authenticity of self-expression (voice), on the other hand (Roberts \& Cooke, 2009, pp.621-622). The authenticity of materials or texts needs to be questioned, though, when they are removed from their original context. This is why Roberts \& Cooke, in accordance with Widdowson (cf. Roberts \& Cooke, 2009, p.622), prefer to talk about authenticity of interaction rather than ('pseudo-') authenticity of materials. Besides, too overt a focus on authentic materials may lead to an impoverishment of language in the Russian language classroom because authentic language used for lower levels might turn out either as inappropriate, humdrum or one-sided. So what is more important is what is done with the material and what it is used for in teaching and testing situations rather than whether it is authentic or adapted. Authenticity of self-expression means that learners should be motivated and sensitized to present their real selves by developing an authentic voice in interactions, which is all the more important when teaching heterogeneous groups of learners and becomes even more complex when testing them.

Hoekje \& Linell (1994) treat authenticity from the point of view of language testing, once again referring to Bachman \& Palmer's competence model and its two approaches to authenticity: a) to which extent test performances replicate 'real life' performances and b) to which extent the interactions between testee, task and context in test settings simulate interactions in target language use situations. The terms we have to deal with here are 'real life' authenticity, on the one hand, and interactional authenticity and situational authenticity, on the other hand.

Marková (1997) differentiates between authentic and inauthentic verbal expression, brought about by the recognition or disapproval of a complementary self/other relationship (Marková, 1997, p.272). Since her concept is embedded in the psychological discourse of social representations of democracy in Central and East European post-communist countries and not in an educational or pedagogic context, her concept will not be discussed here any further. 
Let me summarize the role of authenticity in teaching and testing (see Fig. 1 below). On the one hand, an input, be it an adapted text (emerging in or from the classroom setting) or real / authentic material (coming from the outside world) is used for developing a pedagogic exercise to facilitate learning. On the other hand, setting a (pseudo-) authentic test task is used to assess the learners' achievement or their proficiency. Learners do the exercise by interacting individually or in pairs or groups, by making use of the teacher's help in the learning process, whereas in the testing situation they interact on their own, hereby producing an output based on their individual learner competence that has been developed both in the classroom setting and in the outside 'real' world. The output reveals the authenticity of their performance through selfexpression (in oral or written form) generated by interacting in the classroom when working on an exercise or elicited by input and stimulus of a test task.

For the purpose of illustrating the teaching and testing of sociopragmatics in the Russian language classroom, I will concentrate on competence authenticity and voice authenticity, the former derived from Bachman \& Palmer's (2010) language competence model and the latter modelled on Roberts \& Cooke (2009).

Bachman \& Palmer's model is divided into two areas of language knowledge: organisational $(=$ grammatical and textual) and pragmatic $(=$ functional and sociolinguistic) knowledge. I will work with the rhetorical and conversational organization of texts, one of the subareas of textual knowledge, and natural and idiomatic expression, a subarea of sociolinguistic knowledge. This seems justifiable since a) discourse competence is a subcomponent of pragmatic competence as defined in CEFR (2001, p.123), and b) "authentic learning is always less about materials and more about how they are used" (Roberts \& Cooke, 2009, p.622). The latter statement is similar to Kolotova \& Kofanova's (2012) definition of pragmatics: "knowing the rules of verbal behaviour in various situations." Although Bachman \& Palmer's language competence model is rather complex, I have decided to use it both for teaching and testing since it is suitable for developing adequate tests of L2 learners' proficiency by using (parts of) the model as test construct. The feedback forwarded to pupils and / or students should be based on a valid interpretation of their test or exam performances. It is Piotrowski (2011, p.222) who reminds us that classroom communication draws "the learners' attention to the [authentic] process of task performance." In other words: the relationship between test features and target language use context has to be close if we want to speak of test authenticity, which promotes construct validity. 
Figure 1. Authenticity in the language classroom

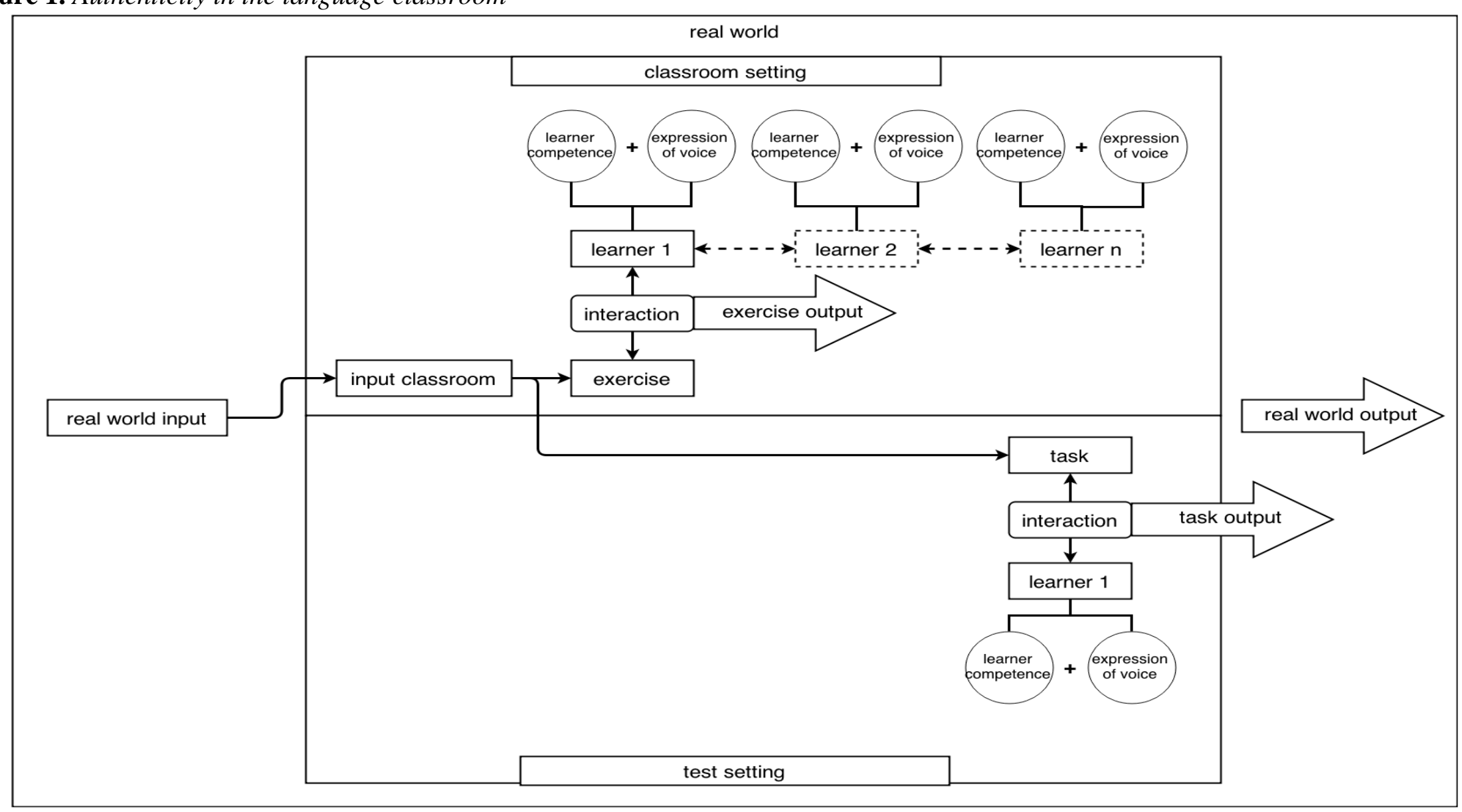




\section{Testing Sociopragmatics}

Research literature on testing sociopragmatics in any language other than L1 mainly deals with the testing of English as a second language. There is comparatively little literature on the teaching and testing of sociopragmatics of Russian as a foreign language, apart from e.g. Narzieva (2005), Dykstra (2006) or Kolotova \& Kofanova (2012), — to name a few exceptions. Narzieva (2005) deals with the instruction of pragmatics in a Russian language classroom from two perspectives: context-enriched and context-reduced (cf. Dufon, 2008, p.81), using drawings in the context-reduced and videos in the context-enriched setting to back up the learning and understanding of apologies and requests respectively. By exposing learners to listening tasks, Dykstra (2006) investigates pragmatic awareness in the teaching of Russian as a second language, focussing on sociocultural dynamics and restraints expressed by the use of the personal pronouns ty (ты) / vу (вы) as forms of address.

Kolotova \& Kofanova's (2012) work, which is considerably less extensive than Narzieva's or Dykstra's, but has the advantage of presenting concrete examples of pragmatic exercises, refers to Ščcukin's understanding of pragmatic competence: “Прагматическая компетенция - это готовность и умение оперативно ориентироваться в ситуации общения и строить высказывание в соответствии с коммуникативным намерением говорящего и возможностями собеседника, умение выбрать наиболее эффективный способ выражения мысли в зависимости от условий общения и поставленной цели“ (Ščcukin 2007, 140). Ščcukin understands pragmatic competence as an ability to quickly navigate the communication situation in order to build statements in accordance with the speaker's communicative intention and the interlocutor's capabilities. The main focus of his definition lies on 'authenticity of expression', which is brought about by the speaker's ability to plan his/her utterances most effectively in accordance with his/her intention and the conditions of the communication situation.

Roever (2011, p.475) states that in dealing with monologic and dialogic extended texts, discursive and interactional abilities have rarely been included in the assessment of second language pragmatic competence. The construct tested so far has been based on speech act and politeness theories, including the comprehension of implicature and formulaic sequencing. The predominant test formats are written and oral discourse completion tests (DCTs), multiplechoice DCTs, role-plays and self-assessment procedures (Roever, 2011, p.467).

It is understandable that various test formats should be used in order to enhance construct validity. However, in classroom-based assessment (be it at school or at university) exercises, tasks and test formats are often taken from course books or developed by the teachers themselves and usually their main concern is to follow practicability. A limited choice of assessment tasks and a small range of exercises preceding them undoubtedly affect the outcome and interpretation of test results and their generalization. It seems easier to pay attention to isolated grammatical, lexical and semantic features in the first place than to discourse structure and speech style elements, which both cause 
problems for learners but need to be tested differently and often with varying effort. So it is explicable, albeit inexcusable, that classroom constructs of sociopragmatic ability are restricted, when more complex and time-consuming test formats such as open role-plays, video chats or face-to-face interaction are neglected. The use of contextualization clues, the organization of consecutive sequencing, the repertoire of speech styles, the production of routine formulae or the estimating of one's effect on the interlocutor is hardly tested, since these formats are difficult to deal with in classroom-based assessment although they should find their place in pragmalinguistic and sociopragmatic tests.

Some of the above mentioned speech acts in 3.1 may easily figure as item models for a discourse completion test (DCT), even if different situations would have to be found for the testing process. It is necessary to add here that the following examples were used with advanced adult learners in teaching and testing situations at university. So, for classroom use, items would have to be chosen that match the age group, the learners' interests and their competence as described in the test specifications for the particular group or level to do justice to the learning and testing construct.

Table 1. Тестовая единийа 1 (Test item 1)

Вы приехали к своему другу в другой город и живёте у него в гостях. В третий
день вашего пребывания вы возвращаетесь из магазина и обнаруживаете, что
вашего друга нет дома, а ключи вы забыли. Вам придётся попросить телефон у
общего друга из соседней квартиры, с которым вы хорошо знакомы.
Чmо Bbl скажете в этой ситуации?
Bbl:

Similarly, turns from the dialogues mentioned in 3.2 above could also be used as test item (see Tab. 2) or test task (Tab. 3.):

Table 2. Тестовая единица 2 (Test item 2)

Прочитайте первую реплику диалога между матерью и отцом.
- Ты уже знаешь, что наш сын сегодня сказал, что он женится!
Как отец отреагирует в этой ситуации?
Отец: -


Table 3. Тестовое задание 1 (Task 1)

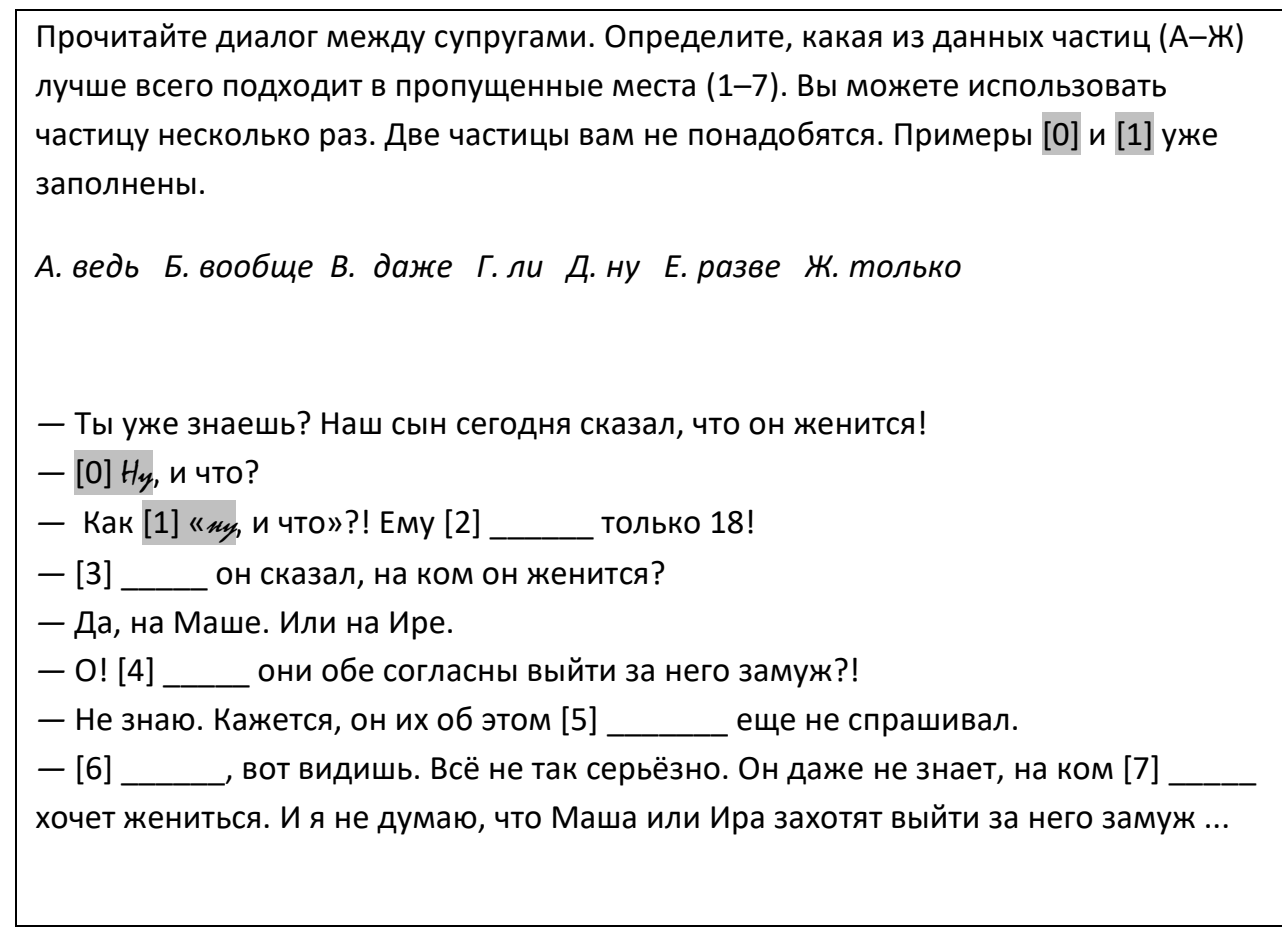

Task 1 (Tab. 3) could also be designed as a multiple-choice task by giving three to four options for each gap, e.g. [2]: Ему [A] ведь / [Б] даже / [B] разве только 18!, with [A] being the correct answer. A second task for more advanced learners could be to leave out the word bank and ask the students to fill in the participles independently. Another task would use an authentic text rather than an adapted or pedagogic one to elicit an emphatic utterance (see Tab. 4):

Table 4. Тестовая единиия 3 (Test item 3)

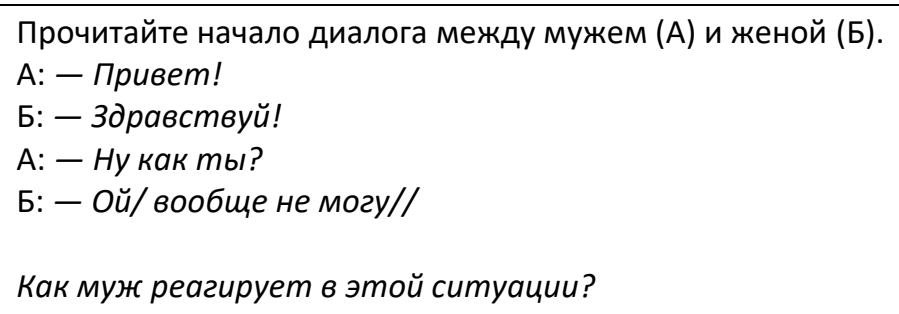

A fourth task could be added in which the learner has to imagine that he has overheard the conversation between his parents. How would he react? What would his first reply to his father or mother be? Students could be asked to either write down the utterance or record it on tape or with their cell-phone.

The idea is to show how we can move from understanding sociopragmatic 
features in adapted texts to applying these features independently in various speech acts, such as oral or written requests and using them autonomously in role plays. Role plays, according to Kasper \& Dahl "represent oral production, full operation of the turn-taking mechanism, impromptu planning decisions contingent on interlocutor input, and hence negotiation of global and local goals, including negotiation of meaning" (Bardovi-Harlig, 2013, p.71). Such tasks - from the receptive to the productive type - result in sociopragmatic language variation, depicting various forms of authenticity, from text authenticity (e.g. authentic conversational organization) to voice authenticity (e.g. authentic idiomatic expression).

The question of how to assess or grade the students' answers unfortunately has to remain unanswered within the scope of this paper.

\section{Suggestions}

Since there is hardly any research concerning the use of sociopragmatic elements in the Russian language classroom and in testing situations, empirical research and corpora studies need to be carried out in order to raise teachers' awareness of the necessity to integrate sociopragmatic competence in the teaching and testing process. Textbook authors need to make use of these findings in order to make texts, especially dialogues, more authentic. Item banks need to be set up by closely following the can-do descriptors of the CEFR levels and the contents of Russian textbooks in order to have test items available which are conducive to assessing students' sociopragmatic competence. Audio and video files need to be developed so that students can practice their sociopragmatic skills before being tested. Considering the fact that nearly every pupil or student possesses a cell phone and usually makes extensive use of it, it might be worth developing mobile learning apps that help students understand appropriate and inappropriate communication situations by explaining relevant pragmatic and sociolinguistic features.

\section{Conclusion}

The Russian language classroom needs to use both adapted and authentic texts to teach pragmalinguistic and sociopragmatic features. An empirical study carried out by Crossley, Louwerse et al. has shown that there exist "no significant differences between simplified and authentic texts in their abstractness and ambiguity" (Crossley, Louwerse et al., 2007, p.27). As regards cohesion and coherence as well as frequent vocabulary items and syntactic complexity, simplified texts win over authentic texts. They lose in the fields of diversity and causality and they "depend less on complex logical operators" (ibid.). Another reason for not relying exclusively on authentic material is that authentic texts do not necessarily generate authentic tasks. Yet authentic texts, be they written for native speakers or a group of language learners, 
communicate information, and their language helps to develop and improve the learners' ability to express themselves authentically. Most of the time, the message of a text is more important than the goal of teaching authentic language per se. A sample review of the literature on teaching and testing sociopragmatics has shown that both the construct and the assessment devices are limited. What is regarded as teachable and testable falls mainly into the paradigms of speech acts (e.g. apologies, compliments, complaints, requests, refusals); discourse markers, pragmatic routine formulae and pragmatic fluency as well as into the realm of implicature comprehension (cf. Kasper, 1997; Roever, 2011). Despite the limitations, it is understandable that these fields should be part of the teaching and testing of sociopragmatics in the Russian language classroom, since teachers can make use of the research results and adapt them to or improve their teaching methods and assessment procedures.

Both the teaching and testing of sociopragmatics must start from an awareness level at an early stage, focusing on receptive skills before moving on to productive skills. The construct for the various competence levels needs to be modelled and broadened by making use of the scales of CEFR and their illustrative descriptors, ranging from sociolinguistic appropriateness (CEFR, 2001, p.122) to flexibility, turn taking (124), thematic development, coherence and cohesion (125), spoken fluency and propositional precision (129).

If the goal in the Russian language classroom is to build up communicative and transcultural competence - apart from grammatical and lexical competence -, then more consideration must be given to the implementation of pragmalinguistic awareness and sociocultural competence in the teaching and testing process. This includes the writing of Russian course books. Authors of text books and teachers of Russian may wish to consider the sociopragmatic construct carefully: which knowledge to teach, which discourse features to develop, which strategies to activate, which interaction schemata to present, which functions and registers to equip their learners with, which politeness conventions to introduce and which authenticity to expose their learners to so that they are able to master the rules of communicative behaviour in various situations.

\section{References}

Bachman, F.L. \& Palmer, A.S., 2010. Language Assessment in Practice. Oxford.

Bardovi-Harlig, K., 2013. Developing L2 Pragmatics. In: Language Learning, 63(1), pp. 68-86.

Bardovi-Harlig, K., \& Mahan-Taylor, R., 2003. Teaching Pragmatics. Washington DC.

Brock, M. N., \& Nagasaka, Y., 2005. Teaching Pragmatics in the EFL Classroom? SURE You Can! In: TESL Reporter, 38(1), pp. 17-26.

Council of Europe, 2001. Common European Framework of Reference for Languages: Learning, teaching, assessment. (=CEFR). Cambridge: Cambridge University Press. 
Crossley, S. A., Louwerse, M. M., McCarthy, Ph., \& McNamara, D. S., 2007. A Linguistic Analysis of Simplified and Authentic Texts. In: The Modern Language Journal, 91, pp. 15-30.

Dufon, M., 2008. Language Socialization Theory and the Acquistion of Pragmatics in the Foreign Language Classroom. In: E. Alcón Soler \& A. Martínez-Flor, Eds. Investigating Pragmatics in Foreign Language Learning, Teaching and Testing. Bristol, Buffalo, Toronto: Multilingual Matters, pp. 57-93.

Dykstra, L. K., 2006. On pragmatic perception: Do learners of Russian perceive the sociocultural weight of the address pronouns? Available from: http://ir.uiowa. edu/cgi/viewcontent.cgi?article $=1251 \&$ context=etd [Accessed 2015-05-24]

Hoekje, B., \& Linell, K., 1994. "Authenticity" in Language Testing: Evaluating Spoken Language Tests for International Teaching Assistants. In: TESOL Querterly, 28(1), pp. 103-126.

Kasper, G., 1997. Can pragmatic competence be taught? In: NetWork \#6 [HTML document]. Honolulu: University of Hawai'i, Second Language Teaching \& Curriculum Center, pp. 1-12. Available from: http://www.nflrc.hawaii.edu/Net Works/NW06/ [Accessed 2015-05-22]

Kolotova, N.I., \& Kofanova, E.I., 2012. Formirovanie pragmatičeskoj kompetencii studentov-filologov v processe isučenija russkogo jazyka kak inostrannogo. In: Učenye zapiski. Ėlektronnyj žurnal KGU 1(21), pp. 1-6. Available from: http://scientific-notes.ru/pdf/023-028.pdf [Accessed 2015-05-23]

Leech, G., 1983. Principles of pragmatics. London.

MacDonald, M. N., Badger, R., \& Dasli, M., 2006. Authenticity, culture and Langauge Learning. In: Language and Intercultural Communication, 6(3/4), pp. 250-261.

Marková, I., 1997. Language and Authenticity. Journal for the Theory of Social behaviour, 27(2/3), pp. 265-275.

Narzieva, L., 2005. The role of context in learning foreign language pragmatics. Master Thesis. California State University.

Piotrowski, S., 2011. On the Authenticity of Communication in the Foreign Language classroom. In: M. Pawlak, E. Waniek-Klimczak \& J. Majer, Eds. Speaking and Instructed Foreign Language Acquisition. Bristol, Buffalo, Toronto: Multilingual Matters, pp. 215-229.

Roberts, C., \& Cooke, M., 2009. Authenticity in the Adult ESOL Classroom and Beyond. In: TESOL Quarterly, 43(4), pp. 620-642.

Roever, C., 2011. Testing of second language pragmatics: past and future. In: Language Testing, 28(4), pp. 463-481.

Röver, C., 2005. Testing ESL Pragmatics. Frankfurt am Main.

Ščcukin, A.N., 2007. Obučenie inostrannym jayzkam: teorija i praktika. Moskva.

Tarasjuk, N.A., \& Konovalova, P.V., 2014. Model' formirovanija pragmatičeskoj kompetencii u mladšich škol'nikov v processe primenenija igrovych straegij na urokach inostrannogo jazyka. In: Vestnik MGGU im. M.A. Šolochova. Pedagogika i psichologija, 1, pp. 37-42. Available from: http://mggu-sh.ru/ sites/default/files/tarasyuk konovalova.pdf [Accessed 2015-05-25] 